\title{
Physico-chemical and sensory evaluation: a case study of the products prepared in Pakistan mineral water and bottling plant, Swabi
}

\author{
Nabila Khan, Abdul Sattar Shah, Ziaur Rahman, Saima Sher Ghani and \\ Hidayat Ullah* \\ Department of Agriculture, University of Swabi, Khyber Pakhtunkhwa- Pakistan \\ *Corresponding author's email: drhidayat@uoswabi.edu.pk \\ Citation \\ Nabila Khan, Abdul Sattar Shah, Ziaur Rahman, Saima Sher Ghani and Hidayat Ullah. Physico-chemical and \\ sensory evaluation: a case study of the products prepared in Pakistan mineral water and bottling plant, Swabi. Pure \\ and Applied Biology. Vol. 5, Issue 4, pp942-949. http://dx.doi.org/10.19045/bspab.2016.50119
}

Received: 08/06/2016 $\quad$ Revised: 22/08/2016 $\quad$ Accepted: 26/08/2016 Online First: 28/08/2016

\section{Abstract}

Beverage intake has become one of the most important parts of our daily life. Most of the liquid requirements are being fulfilled by soft drinks. It has the following phases of production, compounding of ingredients, water treatment, bottle washing, syrup mixing and quality control. This study is related with the carbonated soft drinks being prepared in Pakistan Mineral Water Bottling Plant Gadoon Swabi. Specific standards were there to maintain the quality of the products including different zones for water treatment passing through raw water for the removal of alkalinities and hardness of water. First step of water treatment taking place in reaction tank followed by chemical addition at a specific ratio and then the water is allowed to pass through the buffer tank. Sand filter is used to remove the suspended particles and the water is then allowed to pass through the carbon tank where the carbon in the tank remove the chlorine from water and passed the water to the polisher. In the polisher the spools are present from which the water is filtered. And finally water is passed from the Ultra Violet rays to minimize any microbial activity and then the treated water has been passed to syrup room for preparation of the syrup for different products. Storage tank has the function to check the brix value of the solution and then the concentrates are added at a specific ratio i.e. citric acid, sodium benzoate and sodium citrate. Carbo-cooler is used to cool and dilute the syrup. Liquid ammonia is used for cooling purpose and carbon dioxide is also added in carbo cooler. Before filling, capping and coding of the packages are made as per recommended standards.

Keywords: Brix meter, Carbonated beverage, PH meter, Swapping stick, Torque measuring machine

\section{Introduction}

A beverage or drink is a form of liquid, which has been prepared for human consumption [1]. This can include a number of different steps, some prior to transport, others immediately prior to consumption. Water is the chief constituent in all drinks, and the primary ingredient in most. Methods 
for purification include filtration and the addition of chemicals, such as chlorination [2]. The importance of purified water is highlighted by the World Health Organization, who pointed out $94 \%$ of deaths from diarrhea 'the third biggest cause of infectious death' worldwide at 1.8 million annually could be prevented by improving the quality of the victim's environment, particularly safe water [3]. Carbonated drinks refer to drinks which have carbon dioxide dissolved into them. This can happen naturally through fermenting and in natural water spas or artificially by the dissolution of carbon dioxide under pressure. The first commercially available artificially carbonated drink is believed to have been produced by Thomas Henry in the late 1770s [4]. Cola, orange, various roots, ginger, and lemon/lime are commonly used to create non-alcoholic carbonated drinks; sugars and preservatives may be added later [5]. The most consumed carbonated soft drinks are produced by three major global brands: Coca-Cola, PepsiCo and the Dr Pepper Snapple Group [6]. As flavored carbonated beverages gained popularity, manufacturers struggled to find an appropriate name for the drinks like "marble water," "syrup water," and "aerated water." The most appealing name, however, was "soft drink," adapted in the hopes that soft drinks would ultimately supplant the "hard liquor" market [7]. Microbial contamination of soft drinks usually originates during the production process. The raw materials, factory environment, microbiological state of the equipment and packages, and lack of hygiene are all possible factors [8].

Carbon dioxide is colorless and flavorless. It's this acid that creates the tingling on your tongue. Carbonated Beverages generally indicates a non-alcoholic beverage. When carbonated water has been placed in a bottle, it would create an enormous amount of pressure on whatever was used to close that bottle [9]. This could lead to air escaping, causing the drink to go flat. During this time hundreds of patents were filed for cork, and cap method, all of which were unsuccessful in keeping the bottles sealed overtime [10]. The problem was finally solved by William Painter, a machine shop operator based out of Baltimore, who invented the Crown Cork Bottle Seal in 1892 [11]. This method was quite successful in keeping the air sealed in the bottle, and allowed for the widespread distribution of a variety of carbonated sodas. The 1920's saw dramatic growth in the popularity of the soft drink, as vending machine started to appear in public places [12]. This was also when the "Home Pak" was invented; a clever marketing tactic that bundled several bottles or cans, usually a derivative of six, and sold them as boxed sets. "Home-Paks" are the familiar six-pack beverage carrying cartons made from cardboard. This internship was carried out at the Pakistan Mineral Water and Bottling Plant, for their products prepared as per the standard operations.

\section{Materials and methods}

Following steps were taken at Pakistan Mineral Water and Bottling Plant Gadoon Swabi for the preparation of different types of products.

\section{Water treatment}

Water treatment means the removal of all those impurities which harmful for our health and also for our life. Mostly the three types of problems are encountered in the raw water: The physical problem is turbidity, color, odor and taste. The physical problem can greatly be reduced by physical method like filtration etc. Sanitary problem refers to the microbial load, organic salts and organic matter content. Raw water alkalinity and hardness are very important chemical problems in the water [13].

\section{Water standards}

As water is the main constituent of beverages and also any odor, color and 
flavor are undesirable, so in Pakistan Mineral Water and Bottling Plant Gadoon Swabi have some water standards in order to be fixed with concentrates to make the beverage (Table 1). Odor or any flavor in the water makes it rejected by the consumer [14].

Table 1.Water standards used by Pakistan Mineral Water and Bottling Plant Gadoon, Swabi for the preparation of different products

\begin{tabular}{|l|l|}
\hline Parameters & Limit (unit) \\
\hline Taste & Tasteless \\
\hline Odor, color, turbidity, residual chlorine, organic matter, micro-organism & $\leq 0.00$ \\
\hline TDS & $500 \mathrm{ppm}(\max )$ \\
\hline Iron & $<0.01 \mathrm{ppm}$ \\
\hline Total alkalinity & $40-50 \mathrm{ppm}$ \\
\hline Hardness & $150 \mathrm{ppm}$ \\
\hline
\end{tabular}

These standards are constant by the industry, if some changes start to occur then remedial steps are taken to bring them to normality

\section{Water treatment process}

The water for beverage production should be clear by certain process. For chemical clarification of water three basic raw chemicals are being used i.e. lime $\mathrm{Ca}(\mathrm{OH})_{2}$, Bleaching powder $\mathrm{CaOCl}_{2}$, and Ferrous Sulphate $\left(\mathrm{FeSO}_{4}\right)$ water is pumped from the storage tank into the reaction tank by motors.

\section{Reaction tank}

Reaction tank of the Pak Mineral Water and Bottling Plant has a capacity of 60,000 liter.

When water is pumped into the reaction tank there is a dozing system on the upper surface of the reaction tank. Dozing system puts the lime, $\mathrm{FeSO}_{4}$ and chlorine solution at the top of the reaction tank. The solutions are added from the dozing system into the reaction tank at proper rate. The reaction tank consists of four (4) zones.

\section{Mixing zone}

Raw water is mixed with chlorine, $\mathrm{FeSO}_{4}$ solution and lime solution through agitation. Chlorine is added in to raw water for bleaching as well as killing microbes. This zone also makes effective collisions among particles of the chemical of the raw water, lime solution $\mathrm{FeSO}_{4}$ and bleaching powder solution in the reaction zone.

\section{Reaction zone}

This zone is called reaction zone because chemical reaction take place here. In this zone the direction of flow of water is downward. In the reaction zone the following chemical reaction take place such as coagulation reaction, alkalinity reduction reaction and floc formation. Ferrous is converted to ferric by the action of chlorine. Coagulation in water treatment is a process where suspended impurities such as turbidity and colors are combined through chemical reaction into longer particles of sufficient density in order that they will settle out of the water. The temperature of water is very important in the process of coagulation.

\section{Setting zone}

The zone where the sludge settles down is known as settling zone. Sludge is the water along with the floc other denser particles settles down in the bottom.

\section{Clear water zone}

When the treated water rises up into circular clarification zone (the outer most zones), the floc tends to remain behind in the form of Sludge where the water is pumped out and is known as clear zone. The pumped water is almost clear from materials. 


\section{Buffer tank}

Water from the reaction tank goes to buffer tank. Two buffer tanks each of 10,000 and 16,000 liters capacity are used. The main function of the buffer tank is that it can give stay to the water where if there is any floc so it may settle down, this tank has the purpose to supply continuous flow water to sand filter tank. Water from the buffer tank is used for the backwash of sand carbon purifier tanks.

\section{Sand filter}

Water from the buffer tank goes to the sand filter. Sand filter removes suspended particles and in the sand filter water enters from the top and leaves from the bottom of sand filter. The sand filter is charged with sand, gravels and stones. The finest particles make up the top layer of the filter with the large gravels at the bottom. There is a pair of sand filtration used in Pakistan Mineral Water and Bottling Plant Swabi, which are used for the period of 12 hours each. Complete service of the tank is done as per the recommendations of the quality assurance agencies.

\section{Carbon purifier}

Chlorine added into the water basically to kill the germs and neutralizes other organic activities, but In Pakistan Mineral Water and Bottling Plant Swabi pair of carbon purifier has the main function to remove chlorine from the water because chlorine is unfit for human health and causing several digestive disorders and it also affects the original taste and flavor of the syrup followed by back washing for 14-15 minutes.

\section{Water polisher}

Water polishing is almost the final stage in the water treatment. In this stage water is passed through water polisher. The polisher contains special filter papers or cotton cartridges, which has polishing media. They are enclosed in the body of nickel-plated brass. These filter help to remove the small gravels or sand particles that come from carbon purifier or sand filter. This thread like filter is also called spools [15].

\section{Ultra violet treatment}

The ultra violet treatment is giving to remove the microbes from the water at the end of the water treatment. The intensity of the water ultra violet unit is about $136 \%$ in Pakistan Mineral Water and Bottling Plant Swabi. It is an additional measure to prevent microbial growth. The water from the ultra violet unit is passed to the syrup room in order to minimize contamination.

\section{Water treatment tests}

Chemical test at water treatment plant for maintaining standard of water is used. It is very important to check the water periodically because there is standard of water to be maintained for beverage production. There are many chemical and microbial tests, which comes under quality control at pre and post product level. Following are some of the tests, which are done frequently at water treatment department at the Pakistan Mineral Water and Bottling Plant. The total alkalinity test, total hardness test, calcium hardness test, magnesium hardness test, residual chlorine test, sludge settling test and turbidity test are done using the standard AOAC protocol [16] for the four beverages i.e. Amrat cola, Amrat lemon lime and Amrat orange. Similarly, iron test is conducted to determine the over dosage of the ferrous coagulant and TDS test is done to evaluate the range (250-450) of TDS in the product [13]. Some other relevant tests are conducted in the Pakistan Mineral Water and Bottling Plant just before the sealing and capping of the product such as gas volume test for the measurement of $\mathrm{CO}_{2}$, Brix test to maintain specific sugar ratio, Titratable acidity test to measure the amount of acid used, $\mathrm{pH}$ measurement to avoid the microbial growth [13], torque test of the sealed bottle, quality cobtrol tests including sensory, physical and chemical tests for the 
color, taste, odor and viscosity of the products. Finally the microbial and swap test are conducted for any microbial colonies [13].

\section{Syrup section}

Syrup is the main functioning section in the beverages industry. Syrup section deals with two different processes (a) simple syrup or hot carbon process 'Simple syrup is a solution of nutritive sweetener and treated water [17]. First, water is added from the water treatment plant into the pasteurizing tank. A known quantity of sugar and activated carbon are added into the pasteurizing tank. Then the temperature of the pasteurizing tank will increase to $85{ }^{\circ} \mathrm{C}$ for 20 mints. Agitation is done in order to obtain the uniform solution. Then the solution is allowed to settle down for 30 to 40 minutes. Solution is then passed from the filter press, which will remove the carbon and other impurities of the sugar. After this a transparent solution is obtained called simple syrup. This simple syrup is passed from the heat exchanger, which cools the syrup to the temperature of about $18-20{ }^{\circ} \mathrm{C}$. Cool syrup is passed to the storage tank where we can check the brix [18]. Similarly final syrup preparation process is done in the finished syrup tank where the desired quantities of concentrates are added to the storage tank.

\section{Composition of different products Amrat orange}

For the preparation of Amrat orange take 4100 liters volume in orange syrup, for the preparation of about $4 \mathrm{~kg}$ of 2 units orange syrup along with Sodium benzoate of $3 \mathrm{~kg}$ in 2 units, citric acid of $32 \mathrm{~kg}$ in 2 units and flavors of $16 \mathrm{~kg}$ for the preparation of 2-unit volume of orange syrup.

\section{Amrat lemon lime}

For the preparation of Amrat lemon lime 3400 liter volume is required for Amrat lemon lime syrup preparation of 2 units along with sodium benzoate of $3 \mathrm{~kg}$, citric acid of $30 \mathrm{~kg}$, sodium citrate of $4 \mathrm{~kg}$, flavor of $14 \mathrm{~kg}$ and part $\mathrm{C}$ (trade secret) used as $1.75 \mathrm{~kg}$ for 2 units.

\section{Amrat cola}

For Amrat cola syrup preparation 3400 liter of volume is required along with part A @ $31 \mathrm{~kg}$ for 2 units, part B @ $31 \mathrm{~kg}$ and part C @ $4 \mathrm{~kg}$ is being added.

\section{Filling section and carbo-cooler section}

The finished syrup when thoroughly prepared in the finished syrup tank is ready for filling and carbonation. A carbo cooler is a large stainless tank in which the syrup is cooled and then carbonated. For cooling there are two plates in the tank having coils in them. Liquefied compressed ammonia circulates in these coils. This cools the incoming syrup to $4{ }^{\circ} \mathrm{C}$. The properly diluted syrup is pumped into the carbo cooler from the top in the form of the fine spray. At the same time when syrup is being cooled carbon dioxide is injected in to the carbo cooler through an opening at a lower portion in the tank. This opening is connected to the carbon dioxide supply pipeline. The pressure of carbon dioxide in carbo cooler is maintained about 55 to 60 psi. The raisins can wash the bottles. In Pakistan Mineral Water and Bottling Plant Swabi, there are four lines each one for specific product materials such as line- 2 for cans washing. Similarly, filler mechanism is available to fill the bottles followed by capping of bottles with the help of three capper machines of different capacity. Inspection of filled bottles is a routine and quality practice and coding is done to each bottle followed by physical checkup in the inspection section and the faulty stock is rejected. Packaging is done in the dispatch room with certified and environment friendly plastic materials through caser machine

\section{Results and discussion}

Different syrup standards used in Pakistan Mineral Water and Bottling plant Swabi has 
been given in Table 2 . It was noted that $1718 \mathrm{~kg}, 1888 \mathrm{~kg}$ and 2076 of sugar in a single batch were used for the preparation of Amrat cola, Amrat lemon lime and Amrat orange respectively in Pakistan Mineral Water and Bottling Plant Swabi. Similarly, the quantity of water was 1700 liter for cola and lemon lime and for orange it was about 1930 liter. Brix value for simple syrup was kept as $46 \pm 0.2$ for cola and 49.5 for lemon however, it was $43.0 \pm 0.2$ for orange. The finished syrup brix values were 42.5 for cola 46.0 for lemon lime and for orange about $42.8 \pm 0.2 \%$. The titratable acidity was also measured in the Pakistan Mineral Water and Bottling Plant Gadoon Swabi for quality control. The Titratable acidity ranged for PET (Poly Ethylene Treptalate) and Can from 22.0 to 26.0 with the target point of 24.0 for Amrat cola. Similarly, the gas volume for Amrat orange ranged from 1.82.6 for pet container and 1.6-2.4 for Cans (Table 3). Regarding Amrat cola, the different admissible values for the standards maintained at Pakistan Mineral Water and Bottling Plant has been given in Table 3 . The brix on the fresh basis ranged from 8.28.6 for the PET as well as for the Can with the target of 8.4. Similarly, titratable acidity range was kept 12.0-16.0 both for PET and for Can for the Amrat cola. However, the gas volume for Amrat Cola in PET packaging was 3.4-4.2 and for Can it was 3.4-4.0 with the target tolerance of gas volume of 3.8 for PET and 3.7 for Can. Different standards for physic-chemical and sensory evaluation at Pakistan Mineral Water and Bottling Plant, Swabi for Amrat lemon lime has been placed in Table 3. For Amrat lemon lime brix on fresh basis ranged from 8.7 to 9.1 for PET with the admissible target of 8.4 however it was 8.9 for the Can. Titratable acidity was also measured for quality control and ranged from 20.0 to 24.0 for PET and for Can with target point of 22.0. Similarly, gas volume for Amrat lemon lime for PET ranged from 3.4-4.2 and for Can it was 3.4-4.0. The acceptable tolerance was \pm 0.4 for PET and \pm 0.3 for Can Amrat lemon lime. Some other end user information has also been recorded and is given in Table 3.3. $\mathrm{pH}$ of Amrat cola, Amrat orange and Amrat lemon lime was 2.5, 3.0 and 2.7 respectively. Similarly, torque values were assessed from three random PET samples and the same are also given in Table 4. Dissolved oxygen was kept at a level of $>0.01 \mathrm{ppm}$ for all the products and the calories in $250 \mathrm{ml}$ container was estimated as 108 for Amrat cola, 133.3 for Amrat orange and 102.5 for Amrat lemon lime.

Table 2. Syrup Standards used for the preparation of Amrat cola, Amrat lemon lime and Amrat orange in the Pakistan Mineral Water and Bottling Plant, Swabi.

\begin{tabular}{|l|l|l|l|}
\hline Parameters & Amrat cola & Amrat lemon lime & Amrat orange \\
\hline Sugar & $1718 \mathrm{~kg}$ & $1888 \mathrm{~kg}$ & $2076 \mathrm{~kg}$ \\
\hline Treated water & 1700 liter & 1700 liter & 1930 liter \\
\hline Simple syrup brix & $46.0^{\circ} \pm 0.2$ & $49.5^{\circ} \pm 0.2$ & $43.0^{\circ} \pm 0.2$ \\
\hline Simple syrup volume & 3000 liter & 3000 liter & 37000 liter \\
\hline Finished syrup brix & $42.5^{\circ} \pm 0.2$ & $46.0^{\circ} \pm 0.2$ & $42.8^{\circ} \pm 0.2$ \\
\hline Finished syrup volume & 3400 liter & 3400 liter & 4100 liter \\
\hline
\end{tabular}


Table 3. Brix, titratable acidity and gas volume of Amrat orange, Amrat cola and Amrat lemon lime for two different packages used in Pakistan Mineral Water and Bottling Plant, Swabi.

\begin{tabular}{|l|l|l|l|l|l|l|l|l|}
\hline \multirow{2}{*}{ Product } & \multirow{2}{*}{ Package } & \multicolumn{2}{|c|}{ Brix on fresh basis } & \multicolumn{2}{c|}{ Titratable acidity } & \multicolumn{3}{c|}{ Gas Volume } \\
\cline { 3 - 9 } & & Target & Range & Target & Range & Tolerance & Target & Range \\
\hline \multirow{2}{*}{$\begin{array}{l}\text { Amrat } \\
\text { orange }\end{array}$} & PET & 11.1 & $10.9-11.3$ & 24.0 & $22.0-26.0$ & 2.2 & \pm 0.4 & $1.8-2.6$ \\
\cline { 2 - 9 } Amrat cola & Can & 11.1 & $10.9-11.3$ & 24.0 & $22.0-26.0$ & 2.0 & \pm 0.4 & $1.6-2.4$ \\
\cline { 2 - 9 } & PET & 8.4 & $8.2-8.6$ & 14.0 & $12.0-16.0$ & 3.8 & \pm 0.4 & $3.4-4.2$ \\
\cline { 2 - 9 } & Can & 8.4 & $8.2-8.6$ & 14.0 & $12.0-16.0$ & 3.7 & \pm 0.3 & $3.4-4.0$ \\
\hline \multirow{2}{*}{$\begin{array}{l}\text { Amrat } \\
\text { lemon lime }\end{array}$} & PET & 8.9 & $8.7-9.1$ & 22.0 & $20.0-24.0$ & 3.8 & \pm 0.4 & $3.4-4.2$ \\
\cline { 2 - 8 } & Can & 8.9 & $8.7-9.1$ & 22.0 & $20.0-24.0$ & 3.7 & \pm 0.3 & $3.4-4.0$ \\
\hline
\end{tabular}

Table 4. pH, torque, dissolved Oxygen and calories content of different products of Pakistan Mineral Water and Bottling Plant, Swabi.

\begin{tabular}{|l|c|c|c|c|c|c|}
\hline \multirow{2}{*}{ Product } & \multirow{2}{*}{ pH } & \multicolumn{3}{|c|}{ Torque } & \multirow{2}{*}{ Dissolved O2 } & \multirow{2}{*}{ Calories (250ml) } \\
\cline { 3 - 5 } & & $\mathbf{1}$ & $\mathbf{2}$ & $\mathbf{3}$ & & \\
\hline Amrat cola & 2.5 & 17.1 & 13.4 & 13.5 & $>0.01 \mathrm{ppm}$ & 108.0 \\
\hline Amrat orange & 3.0 & 18.5 & 18.3 & 12.5 & $>0.01 \mathrm{ppm}$ & 133.3 \\
\hline Amrat lemon Lime & 2.7 & 16.1 & 15.4 & 13.7 & $>0.01 \mathrm{ppm}$ & 102.5 \\
\hline
\end{tabular}

\section{Conclusion}

As short-term internee for this case study at Pakistan Mineral Water and Bottling Plant, Swabi it was noted that specific standards laid down by the quality control agencies were maintained for carbonated soft drinks. Water was taken from the tube wells within the industries. Chemicals ratio was maintained for each product and the suspended particles were allowed to settle down in the buffer tank using integrated circuit sensors. Effective mechanism of sand filter was there for clearing the unwanted particles (if any). Carbon tank has the system to remove chlorine from water and then passed the water to the polisher, which filtered stones and sand particles. Effective process of UV light was there for killing the microbes (if any). All other post product preparations tests were being conducted such brix values and addition of other required standards for the evaluation of the products of Pakistan Mineral Water and Bottling Plant. Similarly, numbers of test were conducted in the lab for the quality of the beverages including brix test, torque test, gas pressure, gas volume, and temperature of the beverage, $\mathrm{pH}$ test and microbial test.

Authors' contributions

Conceived and designed the experiments: N Khan \& AS Shah Performed the experiments: N Khan \& Z Rahman, Analyzed the data: SS Ghani Contributed reagents/materials/analysis tools: $\mathrm{N}$ Khan Wrote the paper: H Ullah

\section{Disclaimer}

This study was undertaken at Pakistan Mineral Water and Bottling Plant, Swabi and the author (s) have used their best efforts in preparing this work with respect to the accuracy. Neither the publisher nor author shall be liable for any loss of profit or any other commercial damages.

\section{References}

1. Johnson, Rachel K, Appel LJ, Brands M, Howard BV, Lefevre M, Lustig RH, Sacks F, Steffen LM \& Judith WylieRosett (2009). Dietary sugars intake and cardiovascular health a scientific statement from the American heart association. Circulation 120(11): 1011-1020. 
2. Gupta VK, Ali I, Saleh TA, Nayak A \& Agarwal S (2012). Chemical treatment technologies for waste-water recyclingan overview. Rsc Advances 2(16): 6380-6388.

3. Anonymous (2007). Combating Waterborne Diseases at the Household Level. World Health Organization p. 11. ISBN 978-92-4-159522-3.

4. Steen D \& Ashhurst P (2008). Carbonated Soft Drinks: Formulation and Manufacture. John Wiley \& Sons pp. 1-2. ISBN 1405171707.

5. Sivasankar B (2002). Food processing and preservation. PHI Learning Pvt. Ltd p. 314. ISBN 8120320867.

6. Anonymous (2013). Soft Drink Industry: Market Research Reports, Statistics and Analysis. Report Linker. Retrieved 10 June 2013.

7. Ashurst PR \& Hargitt R (2009). Soft Drink and Fruit Juice Problems Solved. Woodhead Publishing Oxford UK CRC Press.

8. Parish ME (2009). Food safety issues and the microbiology of fruit beverages and bottled water. In Microbiologically Safe Foods. Heredia N, Wesley I, Garcia S (Eds.) John Wiley \& Sons, New York, NY, USA. pp. 291-304.

9. Glennon RJ (2004). Water follies: groundwater pumping and the fate of America's fresh waters. Island Press.

10. Taber GM (2009). To cork or not to cork. Simon and Schuster.
11. Slade G (2009). Made to break: Technology and obsolescence in America. Harvard University Press.

12. Segrave K (2002). Vending machines: an American social history. McFarland.

13. Mueller DK \& Helsel DR (1996). Nutrients in the nation's waters: too much of a good thing? M. A. Kidd (Ed.). US Government Printing Office.

14. American Public Health Association, American Water Works Association, Water Pollution Control Federation \& Water Environment Federation. (1915). Standard methods for the examination of water and wastewater (Vol. 2). American Public Health Association.

15. Lauria J (2008). Water filtration: Using water treatment to tackle the environmental footprint issue. Filtration \& Separation 45(10): 20-23.

16. AOAC. 2000. Official methods of analysis Association of Official and Analytical Chemists $13^{\text {th }}$ ed. Washington, DC. St. Paul, MN.

17. Letourneau SA, Chan W, Lee T \& Chen H (2007). U.S. Patent Application No. 11/686,173.

18. Kobe S (1986). The Coca-Cola Company. Syrup supply method and apparatus for a post-mix beverage dispenser. U.S. Patent 4:582-223. 